\title{
Peningkatan Ketrampilan Pembuatan Desain Kemasan serta Pemanfaatan Media Promosi dan Pemasaran Online Pada Kube Ash-Shidiqqy dan Pik Abdussalam Jepara
}

Package Design Skill Development and Use of Promotion Media and Online Marketing At Kube Ash-Shidiqqy and Pik Abdussalam Jepara

\author{
Sugiyanto $^{* 1}$, Aisyatul Karima ${ }^{2}$, Auria F.Yogananti ${ }^{3}$ \\ 1,2,3 Fakultas Ilmu Komputer, Universitas Dian Nuswantoro, Semarang \\ e-mail: *11sugiyanto@dsn.dinus.ac.id, ${ }^{2}$ aisyatul.karima@dsn.dinus.ac.id, ${ }^{3}$ yogananti.au \\ (a)dsn.dinus.ac.id
}

\begin{abstract}
Abstrak
Usaha Mikro, Kecil dan Menengah (UMKM) memiliki peranan yang sangat penting bagi pemerintahan Kabupaten Jepara. Kelompok Usaha Bersama (KUBE) Ash-Shidiqqy, merupakan unit usaha bersama yang dibuat oleh ibu-ibu di Desa Margoyoso-Kalinyamatan untuk memberikan pelatihan kemandirian untuk wanita dan janda melalui usaha pembuatan makanan ringan.Pusat Industri Kreatif (PIK) Abdussalam, merupakan komunitas UMKM yang memproduksi: kerajinan monel, kain troso, batik Jepara, kerajinan rotan dan lain-lain. Untuk kemasan produk, keduanya hanya menggunakan plastik tanpa identitas, hal tersebut yang membuat (KUBE) Ash-Shidiqqy dan UMKM dibawah asuhan (PIK) Abdussalamtidak terlalu dikenal masyarakat. Kemasan tidak menarik dan tidak ada standar dari kemasan yang digunakan.Padahal produk-produk tersebut seringkali digunakan sebagai ciri khas produk Kabupaten Jepara. Pemasaran produk-produk yang ada juga terbatas di wilayah UMKM. Dari masalah yang ada, solusi yang ditawarkan adalah menyediakan pelatihan pembuatan Logo, Kemasan serta promosi dan pemasaran produk melalui media online.Dengan solusi yang ditawarkan, UMKM diharapkan dapat membuat desain kemasannya sendiri serta dapat secara mandiri mengoperasikan media promosi dan pemasaran produk melalui media online untuk menaikkan penjualan produk UMKM dan meningkatkan kesejahteraan anggota(KUBE) AshShidiqqydan (PIK) Abdussalam.Luaran yang dihasilkan adalah standar kemasan produk UMKM, media promosi dan pemasaran secara online serta tulisan ilmiah
\end{abstract}

Kata kunci- UMKM, Kemasan, Media Promosi, Pemasaran Online

\begin{abstract}
UMKM have an important role for government Jepara district, as are many and scattered and can provide potential job opportunities. KUBE Ash-Shidiqqy, the business unit with the mothers in the village Margoyoso Kalinyamatan in training independence for women through the business of making snacks. PIK Abdussalam, UMKM community that produces: Monel craft, fabric troso, Jepara batik, rattan, and other.For product packaging, they just use a plain plastic and without identity. Thus, the identity of Ash KUBE-Shidiqqy and UMKM assisted PIK Abdussalam less known to the public. Packaging less attractive and there is no standard product packaging. In fact, these products carry an identity as a typical product of Jepara district. Marketing of products is limited around the territory of the UMKM. Of these problems, given the solution by providing training logo creation, manufacture of packaging, as well as the promotion and marketing of media products online. With this solution, UMKM are expected to be able to make the packaging design independently and able to operate a media campaign and online marketing in order to increase sales of products of UMKM and improve the welfare of members of KUBE Ash-Shidiqqy and PIK Abdussalam. Outputs generated in this devotion is the standard packaging products UMKM, media promotions and online marketing and scientific works.
\end{abstract}

Keywords-UMKM, packaging, media campaign, online marketing 


\section{PENDAHULUAN}

Usaha Mikro, Kecil dan Menengah (UMKM) merupakan memiliki peranan yang sangat penting bagi pemerintahan Kabupaten Jepara, karena jumlahnya sangat banyak dan tersebar dimana-mana, serta dapat memberi kesempatan kerja yang potensial. Peranan UMKM tersebut menjadi bagian yang diutamakan dalam setiap perencanaan tahapan pembangunan pemerintah Kabupaten Jepara, namun demikian usaha pengembangan yang telah dilaksanakan masih belum memuaskan hasilnya, karena pada kenyataannya kemajuan UMKM sangat kecil dibandingkan dengan kemajuan yang sudah dicapai usaha besar. Padahal, UMKM memiliki banyak hal dalam keunggulan diantaranya inovasi dalam pengembangan produk, hubungan kemanusiaan yang akrab, menciptakan kesempatan kerja yang cukup banyak, dan mampu menyesuaikan pasar yang selalu berubah dengan cepat. Keungulan-keunggulan inilah yang bisa digunakan untuk menghadapi persaingan yang semakin ketat, karena semakin terbukanya pasar didalam negeri, merupakan ancaman bagi UMKM dengan semakin banyaknya barang dan jasa yang masuk dari luar dampak globalisasi. Oleh karena itu pembinaan dan pengembangan UKM saat ini dirasakan semakin mendesak dan sangat strategis untuk mengangkat perekonomian rakyat, maka kemandirian UMKM dapat tercapai dimasa mendatang.Dengan berkembangnya perekonomian rakyat diharapkan dapat meningkatkan pendapatan masyarakat, membuka kesempatan kerja, dan memakmurkan masyarakat secara keseluruhan.

Kelompok Usaha Bersama (KUBE) Ash-Shidiqqy, merupakan suatu unit usaha bersama yang dibuat oleh beberapa ibu-ibu di Desa Margoyoso Kecamatan Kalinyamatan Kabupaten Jepara dalam memberikan pelatihan kemandirian untuk wanita dan janda melalui usaha pembuatan makanan ringan. Dalam usaha ini, KUBE Ash-Shidiqqy membentuk kelompokkelompok kecil unit usaha yang merupakan kaum wanita di wilayah tersebut dengan produk sesuai kemampuan masing-masing kelompok. Produk yang sudah dihasilkan oleh KUBE AshShidiqqy adalah Krupuk Bawang dan Krupuk Ikan. Pemasaran produk yang dihasilkan selama ini hanya di wilayah sekitar Desa Margoyoso dengan cara dititipkan ke warung-warung dan dijual ke pasar.

Pusat Industri Kreatif (PIK) Abdussalam merupakan komunitas masyarakat di Desa Kriyan Kecamatan Kalinyamatan Kabupaten Jepara yang membantu mewujudkan kesejahteraan masyarakat yang mandiri dan berkelanjutan melalui UMKM dengan mengutamakan kualitas produk, desain dan kreatifitas. Ada beberapa UMKM yang sudah menjadi binaan PIK Abdussalam ini, antara lain UMKM yang memproduksi : kerajinan monel, kain troso, batik Jepara, kerajinan rotan dan makanan khas Jepara (Kacang Jepara, Kerupuk Bakar).

Produk- produk yang dihasilkan sebagian besar juga masih menggunakan kemasan berupa plastik polos.Identitas produsen seringkali dibuat dalam bentuk kertas yang dilampirkan dalam kemasan plastik tersebut. Hal ini dilakukan dikarenakan sederhananya proses yang dibutuhkan dibandingkan dengan membuat kemasan produk yang permanen. Sehingga, identitas produsen barang tersebut kurang begitu dikenal masyarakat.Padahal produk yang dihasilkan seringkali juga digunakan sebagai oleh-oleh yang dibeli oleh pendatang dari luar kota. Selain kerajinan kain troso dan rotan yang sudah banyak dikenal oleh masyarakat sebagai produk kerajinan mebel Jepara, produk kerajinan monel dan batik Jepara beberapa waktu belakangan ini juga mulai ditonjolkan sebagai produk kerajinan khas Jepara.

Kemasan merupakan salah satu cara untuk mempromosikan suatu produk serta menarik minat konsumen untuk membeli, oleh karena itu kemasan harus sesuai dengan fungsi yang akan dibidik oleh para produsen [1].Kemasan produk merupakan bagian penting dalam sebuah pemasaran, karena kemasan bukan hanya berfungsi sebagai pembungkus produk, namun untuk menambah nilai jual suatu produk [2].

Lingkup pemasaran juga menjadi perhatian. Selama ini, pemasaran produk dari KUBE Ash-Shidiqqymasih disekitar wilayah Kecamatan Kalinyamatan. Sedangkan untuk produkproduk PIK Abdussalam, beberapa produsen sudah menggunakan media sosial dalam pemasaran produknya. Hal ini membuat sulitnya memantau seberapa besar pemasaran produk 
yang sudah dilakukan. Karena masing-masing produsen menggunakan model pemasaran yag berbeda-beda. Selain itu, juga kurang rapi dalam mengelola dokumentasi pemasaran produk.

Untuk memperkenalkan bahwa produk-produk tersebut merupakan produk khas Jepara, diperlukan suatu media publikasi yang sekaligus bisa menjadi media untuk pemasaran produk.Hal ini harus dilakukan agar produk-produk tersebut semakin dikenal oleh masyarakat luas.Berdasarkan hasil penelitian[3] menunjukan bahwa secara simultan variabel bebas promosi online dan persepsi harga berpengaruh signifikan terhadap variabel terikat yaitu keputusan pembelian.

Adapun permasalahan mitra yang menjadi prioritas dari hasil identifikasi yang telah dilakukan adalah sebagai berikut :

a) Belum adanya standar kemasan produk yang sekaligus bisa menjadi alat pemasaran dan identitas UMKM, baik untuk produk berupa makanan atau produk lainnya (kerajinan monel, kain troso, batik Jepara).

b) Dibutuhkannya suatu media promosi dan pemasaran produk onlineuntuk memperkenalkan kepada masyarakat luas bahwa produk tersebut merupakan hasil kerajinan khas Jepara.

Dengan kemasan produk yang baik dan tersedianya fasilitas pemasaran produk secara online memberikan nilai tambah terhadap produk dan produk akan lebih dikenal oleh masyarakat luas. Diharapkan permintaan produk-produk tersebut akan meningkat sehingga produksi pada UMKM juga akan meningkat dan membutuhkan banyak tenaga kerja. Hal ini akan memberikan hasil meningkatnya kesejahteraan masyarakat.

\section{METODE PENELITIAN}

Metode Kualitatif digunakan untuk menjelaskan kegiatan Kegiatan Pelatihan Desain Kemasan Produk dan Pembuatan Media Promosi dan Pemasaran Online. Adapun Kegiatan Pelatihan Desain Kemasan Produk dan Pembuatan Media Promosi dan Pemasaran Online ini dilaksanakan sebagai solusi dari permasalahan yang ada pada Kube Ash-Shidiqqy dan PIK Abdussalam Jepara. Kegiatan ini dilaksanakan melalui beberapa tahap sebagai berikut :

1) Persiapan

2) Pelatihan Pembuatan Logo dan Kemasan

3) Pembuatan dan Pelatihan Sosialisasi Media Promosi dan Pemasaran Online

4) Evaluasi

5) Pembuatan Laporan

\section{HASIL DAN PEMBAHASAN}

\subsection{Pelaksanaan Kegiatan}

\subsubsection{Persiapan}

Tahap persiapan dilakukan dengan melakukan kesepahaman dengan mitra yakni KUBE Ash-Shidiqqy dan PIK Abdussalam Kecamatan Kalinyamatan Jepara. Setelah terjadi kesepakatan kemudian dilakukan perencanaan dan diskusi yang berkaitan langsung dengan masalah yang ada pada mitra dengan alternatif solusi yang bisa dilakukan. Selain itu, dibahas juga tentang agenda kegiatan pelatihan.

Untuk kelancaran pelaksanaan pelatihan, dibuatkan materi-materi berupa modul pelatihan terkait dengan pelatihan logo, kemasan, serta media promosi dan pemasaran online.

\subsubsection{Pelatihan Pembuatan Logo dan Kemasan}

a) Pelatihan Pembuatan Logo

Pelatihan pembuatan logo dilaksanakan pada tanggal 21 Mei 2016, bertempat di PIK Abdussalam Desa Kriyan Kecamatan Kalinyamatan Kabupaten 
Jepara. Pelatihan ini dilaksanakan mulai jam 08.00-17.00 WIB. Peserta yang diundang sebanyak 20 orang yang merupakan anggota KUBE Ash-Shidiqqy dan PIK Abdussalam. Peserta yang hadir mengikuti pelatihan ini sebanyak 16 orang.

Pada pelatihan pembuatan logo ini, peserta dilatih untuk membuat logo sebagai identitas masing-masing UMKM yang nantinya akan diimplementasikan pada kemasan produk.

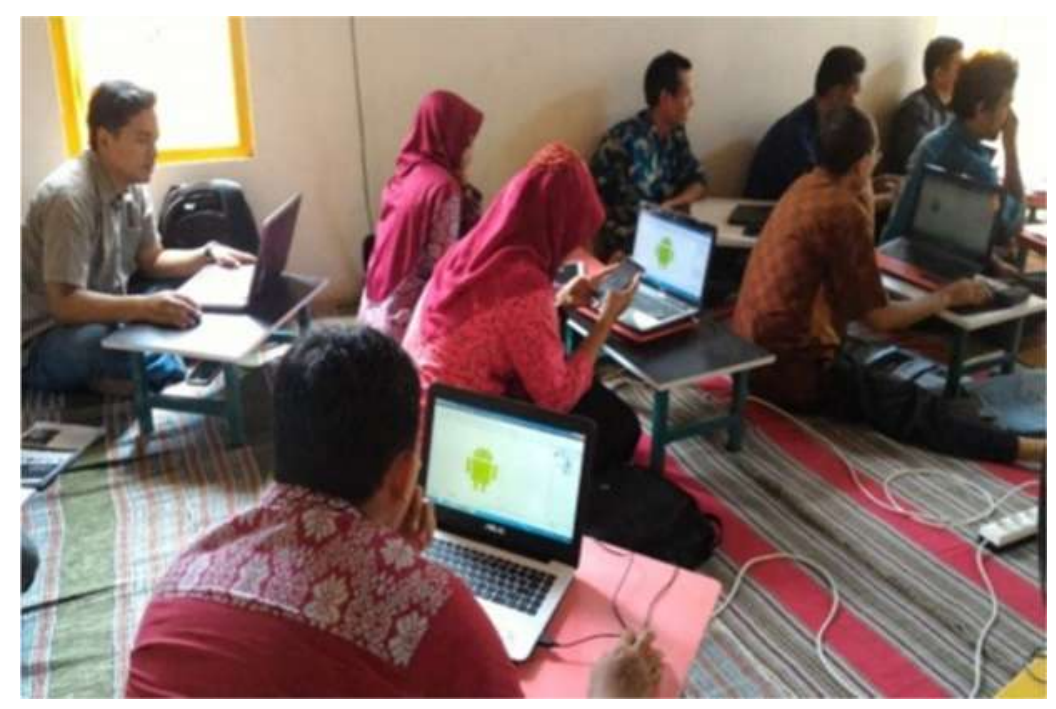

Gambar 1. Pelatihan Pembuatan Logo
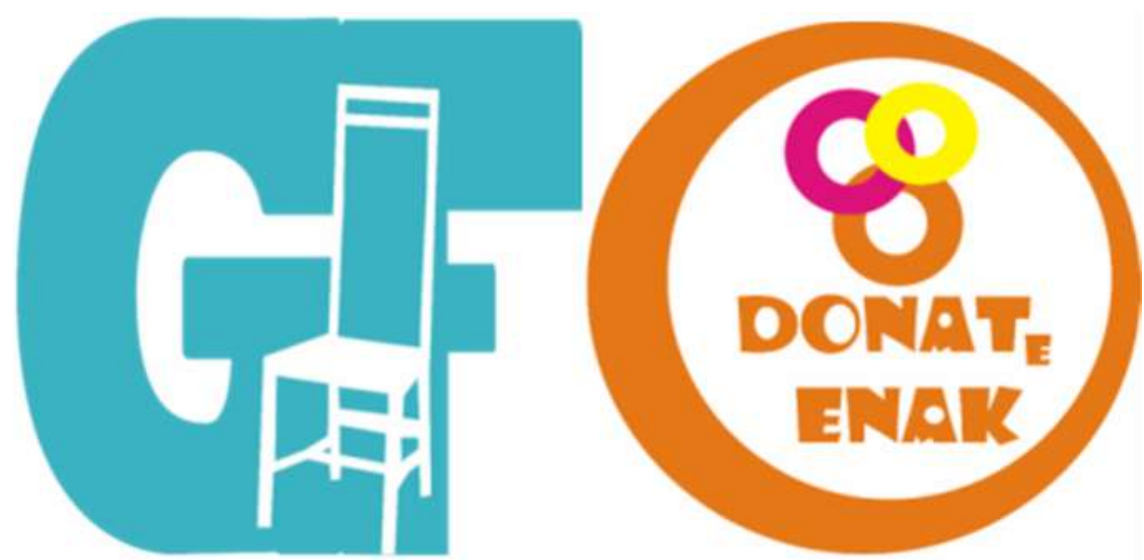

Gambar 2. Contoh Hasil Pembuatan Logo

b) Pelatihan Pembuatan Kemasan

Pelatihan pembuatan kemasan dilaksanakan pada tanggal 31 Juli 2016, bertempat di PIK Abdussalam Desa Kriyan Kecamatan Kalinyamatan Kabupaten Jepara. Pelatihan ini dilaksanakan mulai jam 08.00-17.00 WIB. Peserta yang diundang sebanyak 20 orang yang merupakan anggota KUBE Ash-Shidiqqy dan PIK Abdussalam. Peserta yang hadir mengikuti pelatihan ini sebanyak 13 orang.

Pada pelatihan pembuatan kemasan ini, peserta dilatih untuk membuat standard desain kemasan produk untuk masing-masing UMKM : bentuk, ukuran dan bahan. 


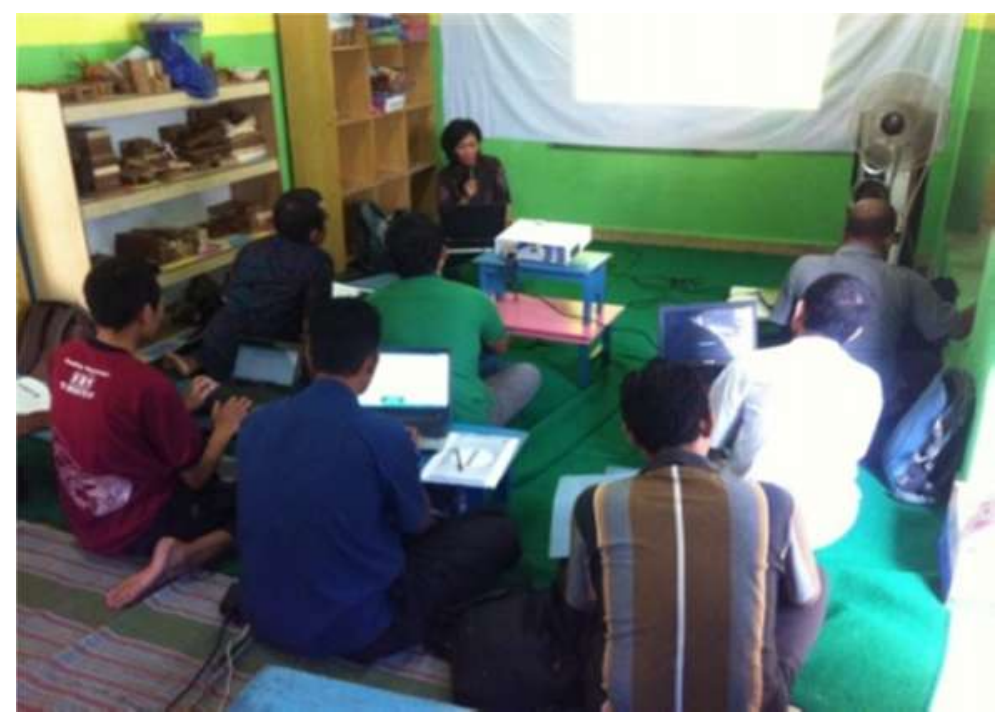

Gambar 3. Pelatihan Pembuatan Kemasan

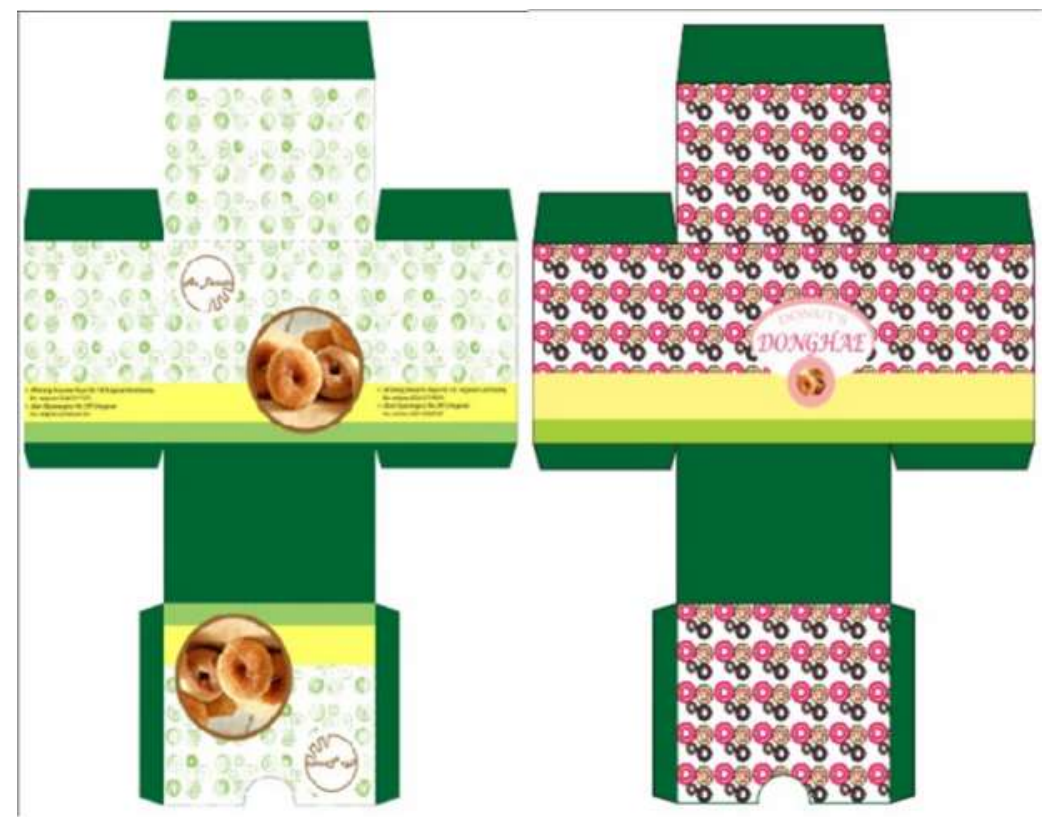

Gambar 4. Contoh Hasil Pembuatan Kemasan

\subsubsection{Pembuatan dan Pelatihan Sosialisasi Media Promosi dan Pemasaran Online}

Pembuatan Media Promosi dan Pemasaran Online dilakukan dalam beberapa tahap :

1) Analisa kebutuhan sistem, menganalisa semua kebutuhan yang akan digunakan dalam sistem : media publikasi, media pemasaran, transaksi order, pembayaran, notifikasi, dll.

2) Pengumpulan dan analisa data, mengumpulkan dan menganalisa data : data UMKM, data produk, kapasitas produksi, poses order, rekening bank, pengiriman barang, dll.

3) Desain system, desain perancangan sistem yang dibutuhkan : pembuatan interface, alur order barang, alur pengiriman, alur retur, alur pembayaran, dll.

4) Pembuatan system, pembuatan prototype system : coding program sesuai dengan desain yang sudah dibuat sebelumnya. 
5) Pengujian system, melakukan pengujian terhadap sistem yang dibuat dengan user acceptance test dan pengujian dengan mitra.

6) Implementasi system, pembuatan domain dan hosting sistem : www.abdussalamcreative.com.

7) Perawatan system, menyiapkan sumber daya yang akan menangani pengoperasian sistem, update data, backup data, perbaikan kesalahan.

Pelatihan Sosialisasi Media Promosi dan Pemasaran Online dilaksanakan pada tanggal 23 September 2016, bertempat di PIK Abdussalam Desa Kriyan Kecamatan Kalinyamatan Kabupaten Jepara. Pelatihan ini dilaksanakan mulai jam 08.00-15.00 WIB. Peserta yang diundang sebanyak 20 orang yang merupakan anggota KUBE Ash-Shidiqqy dan PIK Abdussalam. Peserta yang hadir mengikuti pelatihan ini sebanyak 12 orang.

Pada pelatihan sosialisasi ini, kepad peserta diperlihatkan Media Promosi dan Pemasaran Online yang telah dibuat. Selain itu juga diajarkan bagaimana peserta bisa mengoperasikan sistem : update data produk, penanganan pesanan, dll.

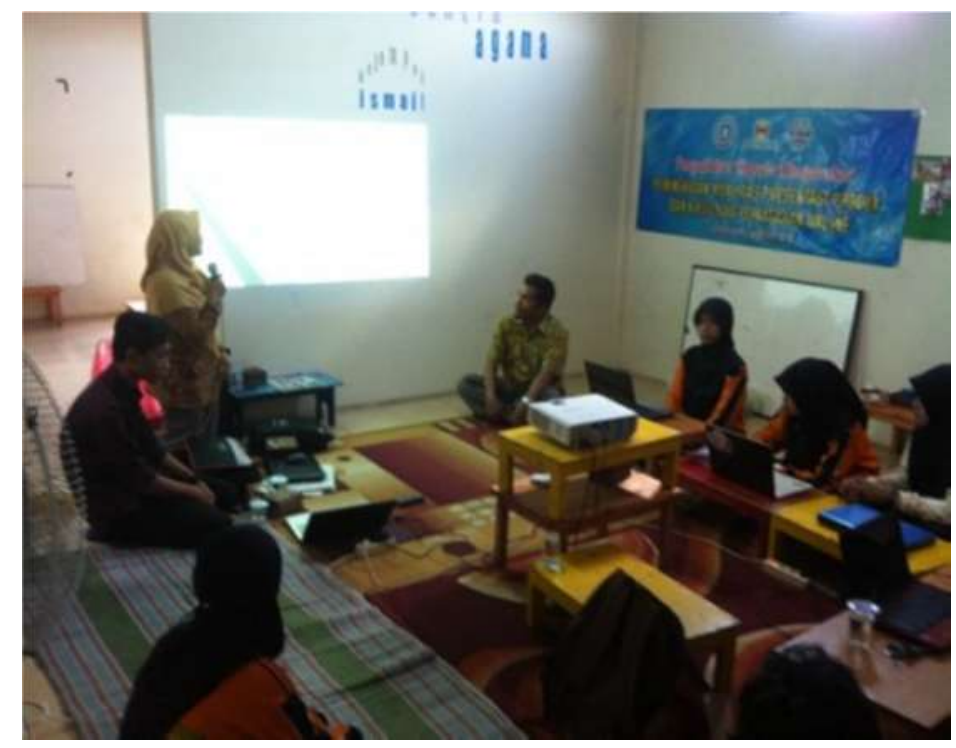

Gambar 5. Pelatihan Sosialisasi Media Promosi dan Pemasaran Online

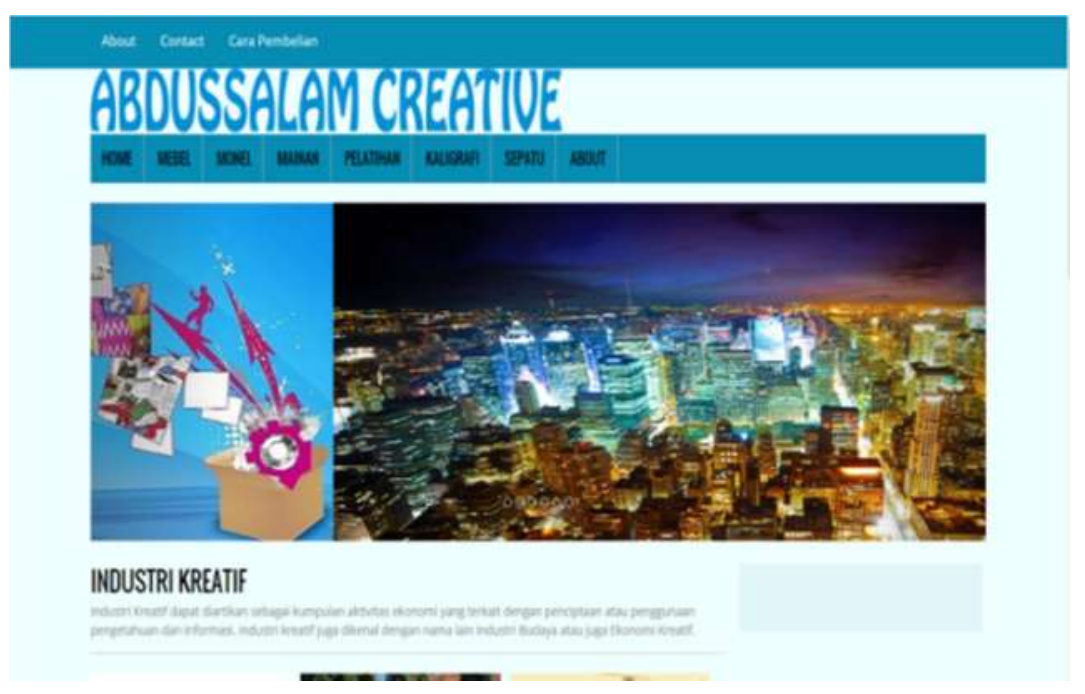

Gambar 6. Hasil Perancangan Media Promosi dan Pemasaran Online 


\subsubsection{Evaluasi}

Evaluasi dilakukan terhadap keberhasilan kegiatan-kegiatan yang telah dilaksanakan.

Ada beberapa hal yang dievaluasi, yaitu:

1) Tingkat kehadiran peserta pelatihan

Pada setiap kegiatan pelatihan, peserta yang diundang sebanyak 20 orang. Dari semua kegiatan pelatihan yang dilakukan, tingkat kehadiran peserta $60-80 \%$.

2) Keaktifan peserta dalam pelatihan

Peserta selalu diberikan penugasan sesuai dengan pelatihan yang dilakukan. Dari sejumlah peserta yang mengikuti pelatihan, $30-60 \%$ aktif berkonsultasi tentang tugas yang diberikan dan melaporkan hasil pekerjaan yang dibuat.

3) Akseptabilitas

Semua kegiatan pelatihan dapat diikuti dengan baik oleh peserta. Salah satu kendala terkait dengan pelaksanaan pelatihan adalah beberapa peserta tidak familier menggunakan aplikasi yang digunakan.

4) Kemampuan dan ketrampilan menggunakan Media Promosi dan Pemasaran Online

Ada beberapa kendala terkait dengan implementasi Media Promosi dan Pemasaran Online, dimana tidak semua peserta dapat dengan mudah mengunakan pengelolaan produk. Sehingga ditunjuk 2 orang yang nantinya bertanggungjawab terhadap pengelolaan Media Promosi dan Pemasaran Online.

5) Umpan balik

Peserta minta ada pendampingan lebih lanjut dalam pembuatan logo dan kemasan yang nantinya betul-betul dipakai untuk produk mereka.

\subsubsection{Pembuatan Laporan}

Penyusunan laporan dilakukan setelah semua kegiatan dilaksanakan dari tahap Persiapan, Pelatihan Pembuatan Logo dan Kemasan, Pembuatan dan Pelatihan Sosialisasi Media Promosi dan Pemasaran Online dan tahap Evaluasi.

\subsection{Hasil Pelaksanaan Kegiatan}

Beberapa kegiatan pelatihan yang telah dilakukan memberikan dampak peningkatan kemampuan ketrampilan yang signifikan bagi peserta, antara lain :

1) Peserta mendapatkan pengetahuan tentang bagaimana membuat desain logo yang baik, penggunaan aplikasi pembuatan logo dan kemasan, penggunaan warna sesuai identitas UMKM, desain kemasan, pemilihan bahan, dll.

2) Peserta memiliki standar kemasan sesuai dengan masing-masing produk.

3) Peserta dapat mengelola Media Promosi dan Pemasaran Online.

\section{KESIMPULAN}

Dari serangkaian pelaksanaan kegiatan pelatihan yang telah dilaksanakan, dapat disimpulkan sebagai berikut :

1) Pelatihan pembuatan desain logo serta pembuatan desain kemasan produk (packaging) telah meningkatkan ketrampilan peserta dalam pembuatan logo dan kemasan untuk produk mereka.

2) UMKM memiliki fasilitas Media Promosi dan Pemasaran Onlineuntuk meningkatkan penjualan produk.

3) Respon para peserta pelatihan cukup positif, hal ini terbukti dengan penyambutan yang diberikan kepada tim pelaksana dengan sangat baik. 


\section{SARAN}

Saran untuk pelaksanaan kegiatan ini adalah desain logo dan kemasan produk yang dihasilkan bisa dikembangkan lagi menjadi pola desain yang lebih atraktif dan lebih menarik lagi.Hal ini bertujuan untuk meningkatkan daya tarik calon konsumen untuk membeli produk yang dimiliki oleh para peserta.

\section{UCAPAN TERIMA KASIH}

Sugiyanto, Aisyatul Karima, dan Auria F.Yogananti adalah dosen Fakultas Ilmu Komputer Universitas Dian Nuswantoro Semarang, yang pada saat ini sedang melaksanakan program pengabdian Masyarakat " $\mathrm{I}_{\mathrm{b}} \mathrm{M}$ Pelatihan DesainKemasan Produk dan PembuatanMedia Promosi dan Pemasaran Onlinepada Kube Ash-Shidiqqy dan PIK Abdussalam Jepara". Ucapan terimakasih disampaikan kepada 1). KUBE Ash-Shidiqqy dan PIK Abdussalam yang telah bersedia menjadi mitra dalam kegiatan ini, 2). Kementerian Riset, Teknologi dan Pendidikan Tinggi Republik Indonesia, yang telah memberikan dukungan pendanaan kegiatan ini melalui Program Ipteks Bagi Masyarakat Tahun Anggaran 2016 yang dituangkan dalam surat perjanjian penugasan dalam rangka pelaksanaan program pengabdian masyarakat batch 1 pada LP2M Universitas Dian Nuswantoro Nomor: 023/A.35-02/UDN.09/V/2016.

\section{DAFTAR PUSTAKA}

[1] R. Harminingtyas, "Analisis Fungsi Kemasan Produk Melalui Model View Dan Pengaruhnya Terhadap Keputusan Pembelian Konsumen Pada Produk Rokok Kretek Merek Dji Sam Soe Di Kota Semarang," Jurnal Stie Semarang, Vol 5, NO 2, ISSN : 2252-7826 Edisi Juni, 2013.

[2] N. C. Purnomo, I. G. N. Ardana and C. T. Handoko, "Perancangan Kemasan dan Media Promosi Kue Gandjel Rel Khas Kota Semarang," Universitas Kristen Petra, Surabaya, 2013.

[3] A. Jamaludin, Z. Arifin and K. Hidayat, "Pengaruh Promosi Online dan Persepsi Harga terhadap Keputusan Pembelian," Jurnal Administrasi Bisnis (JAB), vol. 21, 1 April 2015. 